\title{
Painful neuropathy due to intraneural leukemic spread in a patient with acute myeloid leukemia
}

Figure Sural nerve biopsy results
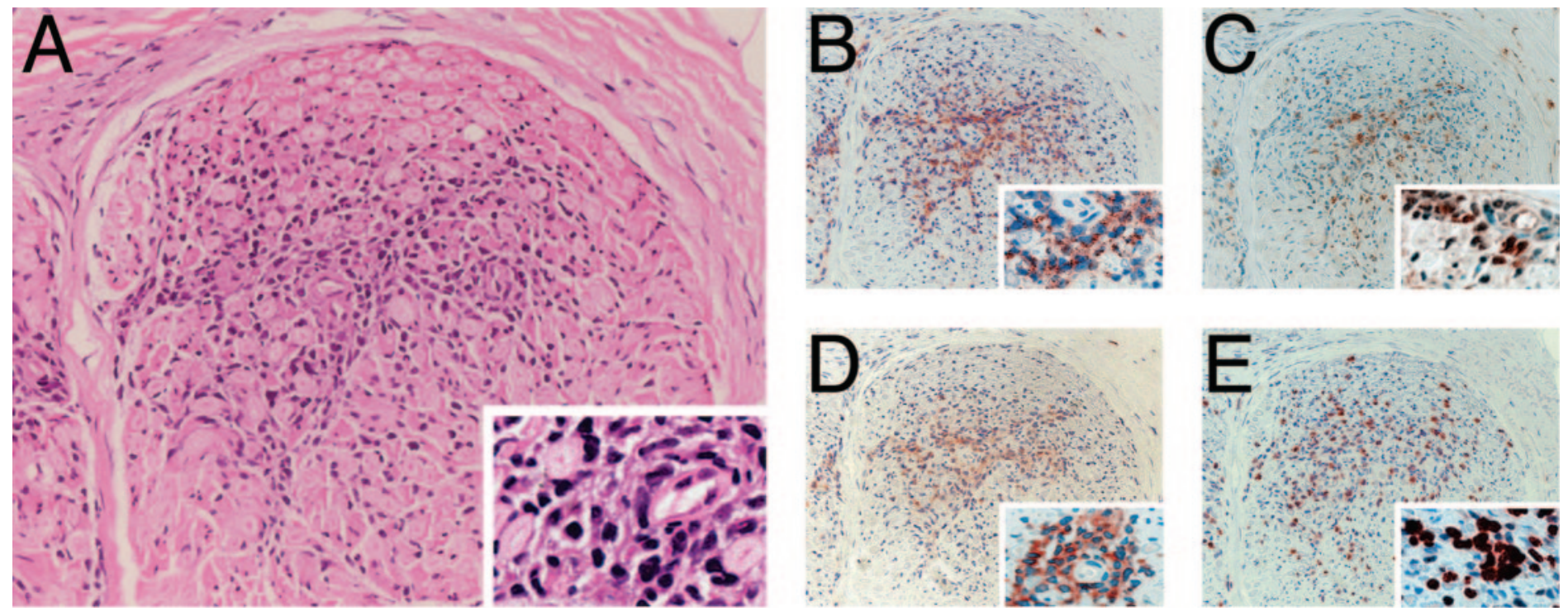

Hematoxylin and eosin staining (magnification $\times 100$, inset $\times 400$ ) of a sural nerve fascicle with infiltrates of pleomorphic lymphoid cells with large nuclei (A). Lymphoid cells express CD45 (B), lysozyme (C), and CD117 (D), signifying myeloid leukemic cells. Ki-67 equivalent antigen (MIB-1) staining reveals a proliferation index of $>70 \%$ in tumor cells ( $E$, magnification of immunostains $\times 100$, insets $\times 400$ ).

A 33-year-old man with acute myelogenous leukemia developed a rapidly progressive painful neuropathy with symmetric sensorimotor and autonomic deficits 7 weeks after chemotherapy. Nerve conduction studies showed axonal sensorimotor neuropathy. Because of the rapidly progressive course, a sural nerve biopsy was performed, which showed intraneural leukemic infiltrates (figure). This case illustrates a rare but important differential diagnosis in patients with peripheral neuropathy and hematologic malignancies. ${ }^{1,2}$ The diagnosis would have been missed without a sural nerve biopsy, and aggressive chemotherapy might have been withheld owing to presumed toxic neuropathy as a result of previous chemotherapy.

M. Platten, MD; C.A. Opitz, MD; P. Kohlhof, MD; U. Hegenbart, MD; A.D. Ho, MD; and W. Wick, MD, Heidelberg, Germany

Disclosure: The authors report no conflicts of interest.

Address correspondence and reprint requests to Dr. M. Platten, Department of Neurooncology, University Hospital of Heidelberg, 69120 Heidelberg, Germany; michael.platten@med.uni-heidelberg.de

\section{REFERENCES}

1. Baehring JM, Damek D, Martin EC, Betensky RA, Hochberg FH. Neurolymphomatosis. Neuro-oncology 2003;5:104115.

2. Vital A, Vital C, Ellie E, et al. Malignant infiltration of peripheral nerves in the course of acute myelomonoblastic leukaemia: neuropathological study of two cases. Neuropathol Appl Neurobiol 1993;19:159-163. 


\section{Neurology}

\section{Painful neuropathy due to intraneural leukemic spread in a patient with acute myeloid leukemia}

M. Platten, C. A. Opitz, P. Kohlhof, et al. Neurology 2007;69;707

DOI 10.1212/01.wnl.0000275547.39894.a6

This information is current as of August 13, 2007

\section{Updated Information \&} Services

References

Permissions \& Licensing

Reprints including high resolution figures, can be found at: http://n.neurology.org/content/69/7/707.full

This article cites 2 articles, 0 of which you can access for free at: http://n.neurology.org/content/69/7/707.full\#ref-list-1

Information about reproducing this article in parts (figures,tables) or in its entirety can be found online at:

http://www.neurology.org/about/about_the_journal\#permissions

Information about ordering reprints can be found online: http://n.neurology.org/subscribers/advertise

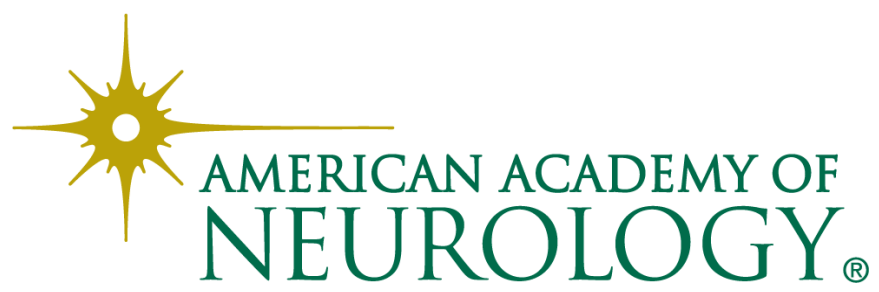

